\title{
OPTIMISATION OF RADIOGRAPHIC PROCEDURES - LUMBAR SPINE IMAGING IN GENERAL RADIOGRAPHY
}

\section{OPTIMIZACIJA POSEGOV V RADIOLOŠKI TEHNOLOGIJI - SLIKANJE LEDVENE HRBTENICE V SPLOŠNI RADIOLOGIJI}

\author{
Erna ALUKIĆ ${ }^{1, *}$, Nika ZALOKAR ${ }^{2}$, Nejc MEKIŠ ${ }^{1}$ \\ 1 University of Ljubljana, Faculty of health sciences, Medical imaging and radiotherapy department, Zdravstvena pot 5, 1000 \\ Ljubljana, Slovenia \\ 2 University Medical Centre Ljubljana, Clinical Institute of Radiology, Zaloška 7, 1000 Ljubljana, Slovenia \\ * Corresponding author: erna.alukic@zf.uni-lj.si
}

Received: 29. 7. 2021

Accepted: 31.8. 2021

https://doi.org/10.47724/MIRTJ.2021.i01.a001

\begin{abstract}
Purpose: Any use of ionizing radiation must be justified and the benefit must be greater than the harm it causes. Imaging must be performed with the lowest possible dose received by the patient, while maintaining optimal radiographic image quality. Imaging of the lumbar spine is a relatively high dose imaging procedure. This systematic review aims to explore optimisation options to reduce patient exposure, while maintaining radiographic quality during plain lumbar spine imaging.
\end{abstract}

\begin{abstract}
Methods: A systematic review of the literature from the databases Pub Med Central, EBSCOhost including CINAHL, Cochrane Library, Web of Science, Science Direct, DiKUL and Springer Link was conducted. The documents were fully accessible and in the English language.
\end{abstract}

Results: 26 experimental studies were included in the analysis. There are many optimisation methods: changing the tube potential, comparison of different projections, use of shielding, primary beam collimation, increasing the source-to-image receptor distance, compression of the imaged area, using the air gap technique, evaluation of the need for additional projections, and rotating the patient depending on the tube side. On average, the dose is reduced by $44 \%$. Studies that also evaluated the quality of radiographs found all radiographs to be diagnostically acceptable.

Conclusion: The results confirm a reasonable use of methods to optimize radiation exposure and to maintain an optimal image quality of radiographs. A systematic review for each specific area in general radiography should be conducted in the future.

Keywords: lumbar spine imaging, optimisation, dose reduction, low dose, image quality

\section{IZVLEČEK}

Namen: Vsaka raba virov sevanja mora biti upravičena, korist, ki jo dosežemo z uporabo ionizirajočih virov pa mora biti večja od škode, kijo povzroči. Postopke slikanja moramo izvajati tako, da pacient pri slikanju prejme najnižjo dozo, ki je še razumno dosegljiva ob optimalni kakovosti rentgenograma. Slikanje ledvene hrbtenice spada med preiskave $z$ relativno visoko dozo ionizirajočega sevanja. Namen sistematičnega pregleda je raziskati možnosti optimizacije v smislu zniževanja doze na paciente in hkratni ohranitvi kakovosti rentgenogramov na področju slikanja ledvene hrbtenice v splošni radiologiji.

Metode: Narejen je bil sistematični pregled literature $s$ pregledom podatkovnih baz Pub Med Central, EBSCOhost preko CINAHL, Cochrane Library, Web of Science, Science Direct, DiKUL in Springer Link. Dokumenti so bili iskani v polnem besedilu in $v$ angleškem jeziku.

Rezultati: V analizo je bilo vključenih 26 eksperimentalnih raziskav. Kot možnosti za optimizacijo so bile uporabljene različne metode spreminjanja napetosti, primerjava različnih projekcij, uporaba svinčenih zaščit, zaslanjanje primarnega polja, povečanje razdalje od izvora do slikovnega sprejemnika, kompresija slikanega področja, ocenjevanje potrebe po dodatni projekciji slikanja ter obračanje pacienta glede na postavitev rentgenske cevi. Povprečna doza ionizirajočega sevanja se zmanjša za $44 \%$. Raziskave, v katerih so poleg doze ocenjevali še kakovost rengenogramov, med ocenami niso opazili statistično značilnih razlik oz. rentgenogrami so bili diagnostično sprejemljivi.

Zaključek: Rezultati potrjujejo smiselno uporabo metod za optimizacijo tako na področju zniževanja doze kot tudi ohranjanja optimalne kakovosti rentgenogramov. V prihodnje bi bilo smiselno narediti sistematični pregled za vsako posamezno področje v splošni radiologiji.

Ključne besede: slikanje ledvene hrbtenice, optimizacija, zniževanje doze, kakovost rengenograma 


\section{INTRODUCTION}

In the last century, population exposure has increased with the use of man-made radioactive sources. Despite the harmful effects of ionising radiation, its use in medicine has significant diagnostic and therapeutic benefits, increasing the frequency of X-ray examinations. Any use of radiation sources must be justified, and the benefit of the use must be greater than the harm it causes $(1,2)$.

Radiation protection results in avoiding unnecessary or unproductive irradiation, which is achieved by general principles of radiation protection. The first principle is the justification principle. The procedure may be performed if it is clinically indicated and if a greater benefit can be expected than the harm caused by the radiation. The referring physician and the radiologist are responsible for the procedure, and they must be familiar with the radiation exposures involved in certain radiologic procedures. The goal is to assess whether the radiological procedure will improve diagnosis or treatment and provide the necessary information. The second principle is the principle of optimisation. Radiation doses and the frequency of patients irradiated must be as low as possible, considering the purpose of the radiation application. Quality and safety are essential characteristics for effective and successful medical treatment of patients. Radiation dose and radiographic image quality must be optimised for proper radiological procedures. Optimising means finding the lowest possible dose at which the purpose of the radiologic procedure is still achieved. By justifying the indication for the radiological procedure and optimising the equipment, techniques, and proper use of radiation sources, the procedure can be optimised. The third principle is the principle of applying dose limits. Departments and facilities may vary in their radiation doses. The causes of these differences must be identified and prevented (3). Radiographic procedures are used only when the diagnosis cannot be made by other methods that are not as risky for the patient (4). We must follow the ALARA principle (As Low As Reasonably Achievable), which means that the procedure must be performed at the lowest possible dose that still gives the optimal quality of the images or procedure $(4,5)$. By reducing the radiation dose, patients are protected from genetic damage (2). According to the 2007 data from International Commission on Radiological Protection (ICRP) 103, the most radiosensitive organs with the highest weighting factor (0.12) are the breasts, lungs, stomach, colon, and bone marrow. The weighting factor of the specific organ represents the average of both sexes and all age groups (3).

Several optimisation studies have been conducted. They are all based on reducing patient exposure whilst still obtaining images of high diagnostic quality. There are no strict guidelines in the European guidelines for performing imaging, but they are supposed to present the basic criteria that have proved appropriate in the past (4). Dose limits do not exist for radiological procedures (6). However, reference values are established for each examination to aid and provide basic guidance in the optimisation of protocols (4). The establishment of reference values is one of the mechanisms by means of which patient overexposure is detected. Diagnostic reference levels (DRLs) represent dose values in diagnostic radiological procedures. They represent a dividing line between optimized and non-optimized radiological practice. DRLs are not expected to be exceeded during optimized procedures. The health authorities set the values in collaboration with the national health and radiation protection authorities (3).

Among the most common reasons for visiting a primary care physician is low back pain leading to imaging of the lumbar spine $(7,8)$. Lumbar spine imaging is one of the examinations with the highest radiation exposure in plain radiography with a relatively high radiation dose (4,9-12). According to the European Commission (13), Slovenia is among the countries where patients receive the lowest dose area product (DAP) values for lumbar spine imaging. Many radiosensitive organs located near the lumbar spine (breasts, lungs, stomach, colon, gonads) must be protected (14).

General principles in accordance with the optimisation of the protocol (4):

- quality control of the radiographic equipment,

- correct positioning of the patient (the proper technique of patient positioning - as the lowest dose with the highest radiogram quality),

- imaging field collimation that leads to a better quality of the radiogram with lower doses,

- use of shielding (protective aprons for radiosensitive organ protection),

- proper exposition parameters (tube current, tube voltage and other parameters that influence the dose and quality of the radiograms) and

- proper image annotation;

Regular checks of the doses received and comparison with diagnostic reference values represent excellent radiological practice as the use of these methods has led to progressively lower exposure doses in many countries (15).

The aim of this systematic review was to investigate optimisation options to reduce the dose to patients while maintaining the quality of radiographic images in plain lumbar spine radiography. The focus was on the lumbar spine imaging, where the patient receives the highest dose in plain radiography. The aim was to investigate all optimisation possibilities in this area for easy transfer to clinical practice.

\section{METHODS}

We performed a systematic review and quantitative analysis. All studies that were included addressed lumbar spine radiography and optimisation, and were fully accessible. The literature search was conducted in English. Since radiography is a relatively new field in which new opportunities for protocol optimisation in terms of the ALARA principle are constantly emerging and new ways of performing examinations are being discovered as technology evolves, no additional restrictions were placed on the selection of studies.

\section{Document references}

Based on the research title, we selected key words that apply to the topic under study. First, we conducted the search in the Pub Med Central, EBSCOhost including CINAHL and Cochrane Library. Since few documents were found, the scope of the study was expanded to include sources found in Web of Science, Science Direct, DiKUL and Springer Link. 


\section{Methods of document identification}

All documents were searched using the following keywords: radiography, lumbar spine and dose reduction. The keywords were selected based on the aim and objectives of this systematic review. The keyword for image quality assessment was not used. Nevertheless, this area was considered. The following exclusion criteria were also used: Magnetic Resonance, Computed Tomography, CT and MRI, as a large number of documents related to MR and CT appeared in the first search.

The retrieved documents were reviewed based on the title and the abstract. All documents that were not suitable for the research were excluded. All documents that did not relate to plain radiography of the lumbar spine and those that did not relate to the process of optimisation or dose reduction were also excluded. Then, all duplicate documents were eliminated. Finally, all articles were read and two documents were excluded because they were not fully accessible and one document did not refer to the study area.

The criteria for including the documents in the analysis were studies covering the topic of plain radiography, lumbar spine imaging, documents that examined dose reduction, documents with full accessibility and in English, as well as quantitative, qualitative, and experimental studies.

Exclusion criteria were all the documents that did not relate to plain radiography imaging, documents that covered other areas of general radiography and did not involve optimisation or dose reduction, and all documents in duplicate or without full accessibility.

\section{Methods for quality evaluation of research}

When evaluating the quality of research works included in this systematic review, a few main features were checked. The following features were taken into consideration:

- a country in which the study was performed,

- research design,

- subjects under investigation (participants),

- inspected area,

- inspected results,

- measurement tools,

- results.

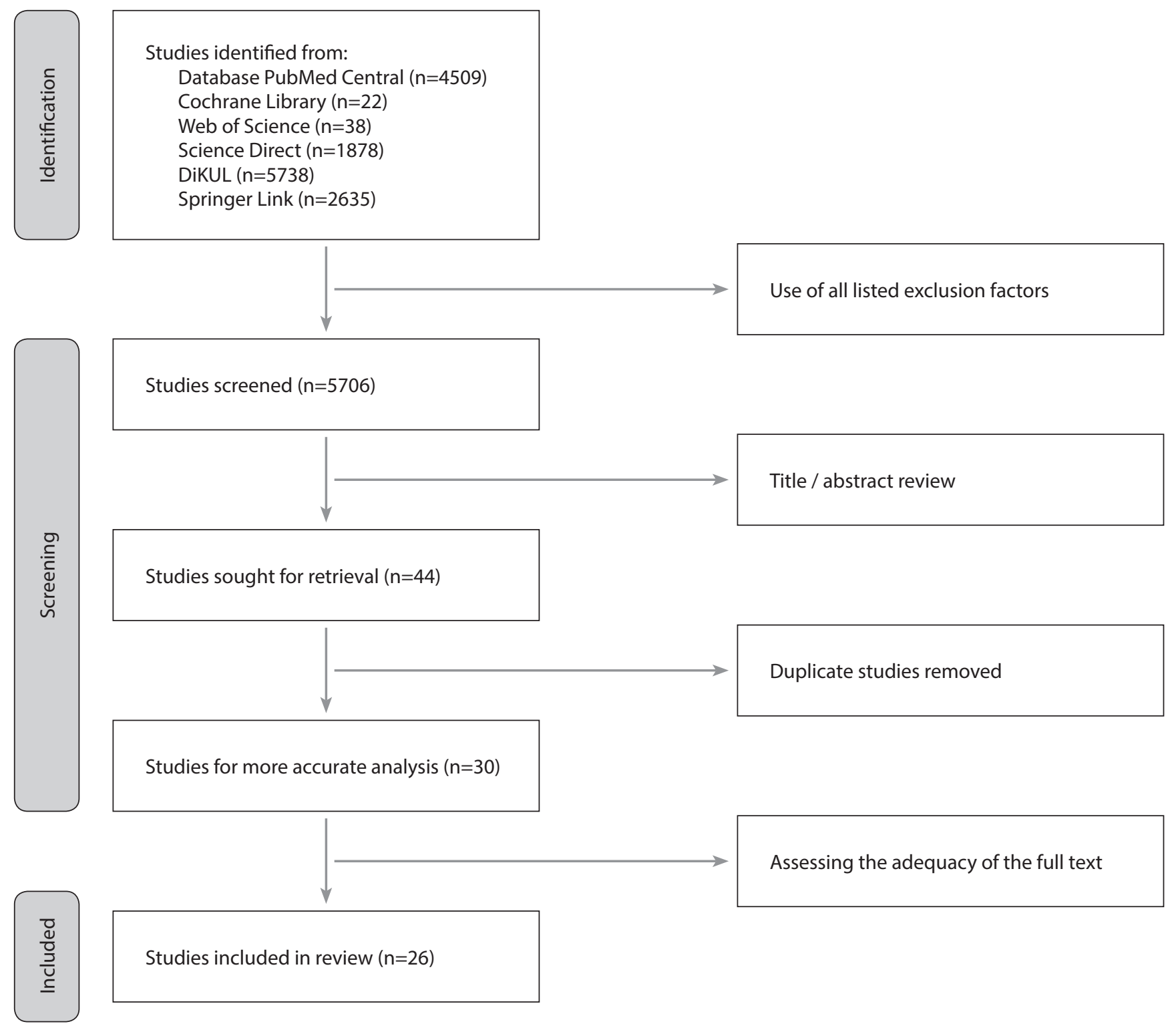




\section{RESULTS}

The literature search in all seven previously mentioned databases yielded 14,832 results (articles). Based on this, exclusion factors were used for several search results. After using exclusion factors, all the articles were screened by title and abstract and all the articles that did not describe lumbar spine radiography or did not describe dose optimisation were excluded. Afterwards, duplicate documents were encountered. After all of the above exclusions had been made, all of the remaining articles were read and four of them were excluded; three were excluded because they were not consistent with the aim of the study and the fourth was excluded because it was not within the scope of general radiography. Figure 1 presents a flow chart of the studies selected.

\section{Main characteristics of investigated papers}

Twenty-six papers were included in our systematic literature review. All key data from our review are presented in Table 1. The data are ordered by year of publication, from the oldest to the most recent. The presented data include the country of research, the research methodology and the reviewed subjects on whom the research was conducted, the reviewed research area, which measurement devices were used, keywords, and finally, the results and conclusions of the research reviewed.

\section{Result analysis}

Papers describing optimisation techniques in lumbar spine radiography have been studied in several countries around the world. Those countries are Finland (16), Australia $(17,34,39,41)$, Ireland (18,19,21,22,25), China (20), Sweden (24,26,33), Kuwait (23), United Kingdom (27,30,36), Slovenia (28,35,37), Iran $(29,32)$, Israel (31), Croatia (38) and Malta (40).

The research methodology was experimental in almost all studies, except for three studies $(16,32,39)$ in which the research methodology was a retrospective study of lumbar spine images. In most cases, the research was performed on an anthropomorphic phantom $(17,20,34,41,22-25,29-31,33)$, in a few studies the research was performed on patients only (27,36-38), and some of them performed a combined study first on a phantom and then on patients $(18,19,21,26,28,35,40)$. The sample size of the examined patient studies varied from study to study. The smallest sample size of patients studied was three (26), and the largest sample size was 110 (38). The investigators studied the radiation dose to the patient and/ or phantom in all papers, but the measurement tool for the dose measurements varied from study to study. The dose was measured using TLDs $(16,18-22,25,28,33)$, ionization chambers $(17,26,30)$, with some mathematical formulas and using conversion factors $(21,23,32)$, DAP meters $(27,35,36,38,40)$, based on calculations with the PCXMC program and Monte Carlo simulation $(24,29-31,35-38,41)$ and other ways $(24,29,34)$. Image quality was not checked in a large number of the papers examined $(17,20,34,37,25-29,31-33)$.

There were several ways to achieve dose optimisation in lumbar spine radiography. In 7 papers, the researchers used different tube potentials (kV) $(21-24,34,39,41)$, different $\mathrm{mAs}(41)$, in 5 papers they used alternative positioning of the patient, in which the patient or phantom was rotated to different positions $(19,27,29-31,35-37)$, and 2 studies used lead shielding as a method of radiation dose reduction $(25,28)$. Four papers investigated increasing the distance (focus-film distance and source-to-image distance) on the radiation dose to the patient during lumbar spine radiography $(17,18,22,41)$, and some of the papers evaluate the effect of proper collimation $(32,33,38)$. Other methods described to reduce radiation dose include the need for additional image projection (16), changing the patient position on the cathode and anode sides of the X-ray tube (20), using a carbon fibre cassette and a faster film/screen combination (22), compression of the body part being examined (26), the effect of an additional copper filter (41), and replacing an antiscatter grid with an air-gap technique (40).

On average, the ESD decreased the most by $65 \%$ (18), dose to gonads by $42 \%$ (25), effective dose by $58 \%$ (29), DAP by $59 \%$ (27) and the dose to other inspected organs decreased the most by $80 \%$, where they evaluate the use of lead shielding to reduce the radiation dose to breasts (28).

Of the 26 reviewed papers, $14(16,18,38-41,19,21-24,30,35,36)$ examined the effect of the optimisation procedure on image quality. In eleven papers, the researchers found no statistically significant difference between image quality before and after optimisation $(16,18,41,19,22,30,35,36,38-40)$. In three others $(21,23,24)$, the researchers concluded that the optimisation procedure decreased image quality but the images were still diagnostically acceptable.

\section{DISCUSSION}

The aim of this systematic literature review was to investigate the options for radiation dose optimisation in lumbar spine radiography. This was selected because lumbar spine radiography is a procedure that delivers the highest radiation dose to the patient in general radiography. There are many ways to achieve dose optimisation in lumbar spine radiography, but all the inspected methods have their limitations. We did not limit our literature review according to the year of publication of the articles as we were interested in the trends of changing measuring equipment, the transition from the film/screen system, and CR and DR detectors.

All the 20 inspected papers offer a large variety of achieved dose reduction in lumbar spine radiography. The method used was mainly experimental. An experimental research method offers the researcher an inspection and testing of new methods for dose reduction and its comparison with previously established methods. In this way, the efficiency and safety of the new protocol can be evaluated. The disadvantage of the experimental method is mainly its ethical concerns; therefore, several researchers investigated their newly established methods on an anthropomorphic phantom $(17,20,34,41,22-$ $25,29-31,33)$ before carrying on with the study on the patients. The use of ionising radiation may negatively affect patients $(1,2)$. However, the ethical concern can be avoided if the newly established research methodology is first performed on a phantom and results of the optimisation procedures are in that manner primarily investigated $(18,19,21,26,28,35,40)$. Some of the investigated papers describe that the research was performed on patients, but many of them performed the primary analysis on a phantom before carrying on with the study on patients.

All the reviewed studies have proven that radiation dose in 
Table 1: Main features of the studies included in the analysis.

\begin{tabular}{|c|c|c|c|c|c|c|c|}
\hline RESEARCH & COUNTRY & $\begin{array}{c}\text { RESEARCH } \\
\text { METHOD \& } \\
\text { SUBJECT }\end{array}$ & $\begin{array}{c}\text { INSPECTED } \\
\text { AREA }\end{array}$ & $\begin{array}{l}\text { AIM OF THE } \\
\text { STUDY }\end{array}$ & $\begin{array}{l}\text { MEASURING } \\
\text { EQUIPMENT }\end{array}$ & KEYNOTES & $\begin{array}{l}\text { RESULTS AND } \\
\text { COCNLUSION }\end{array}$ \\
\hline $\begin{array}{l}\text { Moilanen } \\
\text { et al., } \\
1983 \text { (16) }\end{array}$ & Finland & $\begin{array}{l}\text { Retrospective } \\
\text { study - image } \\
\text { evaluation } \\
n=250\end{array}$ & $\begin{array}{l}\text { Lumbar } \\
\text { spine in } \\
\text { AP, LAT } \\
\text { projection } \\
\text { and lumbo- } \\
\text { sacral joint } \\
\text { (LS) view } \\
\text { in LAT } \\
\text { projection }\end{array}$ & $\begin{array}{l}\text { Evaluation of } \\
\text { the necessity } \\
\text { of LS joint } \\
\text { imaging and } \\
\text { the influence } \\
\text { on gonadal } \\
\text { dose. }\end{array}$ & $\begin{array}{l}\text { Termoluminiscent } \\
\text { dosimeters (TLD) } \\
\text { were used to } \\
\text { measure the dose. } \\
\text { The images were } \\
\text { retrospectively } \\
\text { evaluated by } \\
\text { radiologists. }\end{array}$ & $\begin{array}{l}\text { Film/screen } \\
\text { combination was } \\
\text { used. }\end{array}$ & $\begin{array}{l}\text { In } 91 \% \text { of the cases the } \\
\text { third image (LS joint) } \\
\text { does not contribute any } \\
\text { diagnostic information. } \\
\text { The dose was doubled, } \\
\text { when three projections } \\
\text { are used compared of } \\
\text { two projections. }\end{array}$ \\
\hline $\begin{array}{l}\text { Dilger } \\
\text { et al., } \\
1997 \text { (17) }\end{array}$ & Australia & $\begin{array}{l}\text { Experimental } \\
\text { research } \\
\text { - Phantom } \\
\text { study }\end{array}$ & $\begin{array}{l}\text { Lumbar } \\
\text { spine } \\
\text { (AP and LAT } \\
\text { projection) }\end{array}$ & $\begin{array}{l}\text { Comparison of } \\
\text { radiation dose } \\
\text { to patient at } \\
\text { different focus } \\
\text { film distance } \\
\text { (FFD was } \\
100 \mathrm{~cm} \text { and } \\
200 \mathrm{~cm}) .\end{array}$ & $\begin{array}{l}\text { A chamber } \\
\text { dosimeter to } \\
\text { measure entrance } \\
\text { testicular dose. }\end{array}$ & $\begin{array}{l}\text { Film/screen } \\
\text { combination was } \\
\text { used. }\end{array}$ & $\begin{array}{l}\text { The increase of FFD } \\
\text { decreases radiation } \\
\text { dose for AP projection } \\
\text { by approximately } 30 \% \\
\text { and for LAT projection } \\
\text { by } 70 \% \text {. }\end{array}$ \\
\hline $\begin{array}{l}\text { Brennan } \\
\text { and Nash, } \\
1998 \text { (18) }\end{array}$ & Ireland & $\begin{array}{l}\text { Experimental } \\
\text { research - } \\
\text { Phantom } \\
\text { and patient } \\
\text { study }(\mathrm{n}=21 ; \\
\text { females } \\
\text { between } 55 \\
\text { and } 65 \mathrm{~kg})\end{array}$ & $\begin{array}{l}\text { Lumbar } \\
\text { spine in LAT } \\
\text { projection }\end{array}$ & $\begin{array}{l}\text { Comparison of } \\
\text { radiation dose } \\
\text { to patient at } \\
\text { different focus } \\
\text { film distance } \\
\text { (FFD was } \\
100 \mathrm{~cm}, 130 \mathrm{~cm} \\
\text { and } 200 \mathrm{~cm}) \\
\text { and influence } \\
\text { on image } \\
\text { quality. }\end{array}$ & $\begin{array}{l}\text { Entrance surface } \\
\text { dose (ESD) was } \\
\text { measured using } \\
\text { TLDs. } \\
\text { Image quality } \\
\text { assessment was } \\
\text { performed by two } \\
\text { radiographers and } \\
\text { one radiologist } \\
\text { based on quality } \\
\text { criteria by } \\
\text { the European } \\
\text { Commission. }\end{array}$ & $\begin{array}{l}\text { Film/screen } \\
\text { combination was } \\
\text { used. } \\
\text { entrance surface } \\
\text { dose and dose } \\
\text { to ovaries were } \\
\text { measured. }\end{array}$ & $\begin{array}{l}\text { The larger FFD } \\
\text { resulted in } 65.5 \% \text { of } \\
\text { ESD reduction in the } \\
\text { phantom and } 44.1 \% \\
\text { reduction in the patient } \\
\text { study. } \\
\text { 63-69\% dose reduction } \\
\text { to ovaries when a larger } \\
\text { FFD was used. } \\
\text { There were no } \\
\text { statistically significant } \\
\text { difference in image } \\
\text { quality. }\end{array}$ \\
\hline $\begin{array}{l}\text { Brennan in } \\
\text { Madigan, } \\
2000 \text { (19) }\end{array}$ & Ireland & $\begin{array}{l}\text { Experimental } \\
\text { research - } \\
\text { Phantom and } \\
\text { patient study } \\
(\mathrm{n}=30 ; 70 \pm \\
5 \mathrm{~kg}, 1,55- \\
1,75 \mathrm{~m})\end{array}$ & $\begin{array}{l}\text { Lumbar } \\
\text { spine in } \\
\text { AP and PA } \\
\text { projection }\end{array}$ & $\begin{array}{l}\text { The influence } \\
\text { of PA projection } \\
\text { on ESD and } \\
\text { image quality. }\end{array}$ & $\begin{array}{l}\text { ESD was measured } \\
\text { with TLDs. } \\
\text { The diameter of } \\
\text { the investigated } \\
\text { part was measured } \\
\text { to determine the } \\
\text { compression in PA } \\
\text { projection. } \\
\text { Image quality } \\
\text { assessment was } \\
\text { performed by three } \\
\text { clinicians based } \\
\text { on quality criteria } \\
\text { by the European } \\
\text { Commission. }\end{array}$ & \begin{tabular}{|l|} 
In PA projection \\
the diameter of \\
the investigated \\
part was \\
decreased by \\
$9.6 \%$. That has \\
influenced the \\
AEC to terminate \\
the exposure \\
sooner than in \\
AP projection.
\end{tabular} & $\begin{array}{l}\text { Decrease of ESD in PA } \\
\text { projection by } 38.9 \% \text { in } \\
\text { phantom study and by } \\
38.6 \% \text { in patient study. } \\
\\
\text { There was no } \\
\text { statistically significant } \\
\text { difference in image } \\
\text { quality. }\end{array}$ \\
\hline $\begin{array}{l}\text { Fung in } \\
\text { Gilboy, } \\
2000(20)\end{array}$ & China & $\begin{array}{l}\text { Experimental } \\
\text { research } \\
\text { - Phantom } \\
\text { study }\end{array}$ & $\begin{array}{l}\text { Lumbar } \\
\text { spine in AP } \\
\text { and LAT } \\
\text { projection }\end{array}$ & $\begin{array}{l}\text { Radiation dose } \\
\text { to selected } \\
\text { radiosensitive } \\
\text { organs (ovaries, } \\
\text { testicles, } \\
\text { breasts, } \\
\text { thyroid and } \\
\text { eyes) based } \\
\text { on position } \\
\text { of the patient } \\
\text { regarding } \\
\text { the tube side } \\
\text { (cathode- } \\
\text { anode). }\end{array}$ & $\begin{array}{l}\text { ESD was measured } \\
\text { using TLDs. }\end{array}$ & $\begin{array}{l}\text { Known fact } \\
\text { based on the } \\
\text { literature review } \\
\text { is that there is } \\
\text { higher intensity } \\
\text { of radiation on } \\
\text { the cathode side } \\
\text { of the tube. }\end{array}$ & $\begin{array}{l}\text { When the patient's } \\
\text { head is orientated } \\
\text { towards the anode side } \\
\text { of the x-ray tube, the } \\
\text { ovaries and testicles } \\
\text { received } 17 \% \text { and } \\
12 \% \text { higher dose on } \\
\text { average, respectively, } \\
\text { in LAT projection and } \\
17 \% \text { and } 12 \% \text { higher, } \\
\text { respectively, in AP } \\
\text { projection. }\end{array}$ \\
\hline
\end{tabular}




\begin{tabular}{|c|c|c|c|c|c|c|c|}
\hline RESEARCH & COUNTRY & $\begin{array}{c}\text { RESEARCH } \\
\text { METHOD \& } \\
\text { SUBJECT }\end{array}$ & $\begin{array}{c}\text { INSPECTED } \\
\text { AREA }\end{array}$ & $\begin{array}{c}\text { AIM OF THE } \\
\text { STUDY }\end{array}$ & $\begin{array}{l}\text { MEASURING } \\
\text { EQUIPMENT }\end{array}$ & KEYNOTES & $\begin{array}{l}\text { RESULTS AND } \\
\text { COCNLUSION }\end{array}$ \\
\hline $\begin{array}{l}\text { Doherty } \\
\text { et al., } \\
2003 \text { (21) }\end{array}$ & Ireland & $\begin{array}{l}\text { Experimental } \\
\text { research } \\
\text { - Phantom } \\
\text { and patient } \\
\text { study }(\mathrm{n}=59 \\
70 \pm 10 \mathrm{~kg} \\
1.65 \pm 0.1 \mathrm{~m})\end{array}$ & $\begin{array}{l}\text { Lumbar } \\
\text { spine in AP } \\
\text { and LAT } \\
\text { projection }\end{array}$ & $\begin{array}{l}\text { Increase of the } \\
\text { anode voltage } \\
(\mathrm{kV}) \text { and its } \\
\text { influence on } \\
\text { ESD, effective } \\
\text { dose (ED) and } \\
\text { image quality. }\end{array}$ & $\begin{array}{l}\text { The ESD was } \\
\text { measured using } \\
\text { TLDs, ED was } \\
\text { calculated, and } \\
\text { image quality } \\
\text { assessment was } \\
\text { performed by three } \\
\text { radiologists based } \\
\text { on quality criteria } \\
\text { by the European } \\
\text { Commission. }\end{array}$ & $\begin{array}{l}\text { The increase of } \\
\text { tube voltage } \\
\text { results in faster } \\
\text { termination } \\
\text { of AEC due to } \\
\text { higher energy of } \\
\text { the photons. } \\
\text { The comparison } \\
\text { of tube voltage } \\
\text { in the patient } \\
\text { study was } 81 \mathrm{kV} \\
\text { and } 96 \mathrm{kV} \text { in the } \\
\text { AP and } 90 \mathrm{kV} \text { and } \\
102 \mathrm{kV} \text { in the LAT } \\
\text { projection. }\end{array}$ & $\begin{array}{l}\text { Decrease of ESD by } \\
40.4 \% \text { in AP and } 34.8 \% \\
\text { in LAT projection. } \\
\text { Decrease of ED for } \\
29.9 \% \text { in AP and } 24.6 \% \\
\text { in LAT projection. } \\
\text { The reduction of } \\
\text { image quality in the } \\
\text { AP projection was } \\
18.3 \% \text { and } 10.1 \% \text { in } \\
\text { LAT but all images } \\
\text { were still diagnostically } \\
\text { acceptable. }\end{array}$ \\
\hline $\begin{array}{l}\text { Grondin } \\
\text { et al., } \\
2004 \text { (22) }\end{array}$ & Ireland & $\begin{array}{l}\text { Experimental } \\
\text { research } \\
\text { - Phantom } \\
\text { study }\end{array}$ & $\begin{array}{l}\text { Lumbar } \\
\text { spine in AP } \\
\text { and LAT } \\
\text { projection }\end{array}$ & $\begin{array}{l}\text { Increase of } \\
\text { anode voltage } \\
(\mathrm{kV}), \mathrm{FFD}, \mathrm{c} \\
\text { carbon fibre } \\
\text { cassette, a } \\
\text { faster film/ } \\
\text { screen } \\
\text { combination } \\
\text { and their } \\
\text { influence on } \\
\text { radiation dose } \\
\text { and image } \\
\text { quality } \\
\end{array}$ & $\begin{array}{l}\text { ESD was measured } \\
\text { using TLDs } \\
\text { Image quality } \\
\text { assessment was } \\
\text { performed by two } \\
\text { radiographers and } \\
\text { one physicist based } \\
\text { on quality criteria } \\
\text { by the European } \\
\text { Commission. }\end{array}$ & $\begin{array}{l}\text { Increase of tube } \\
\text { voltage in the } \\
\text { AP projection } \\
\text { from } 66 \mathrm{kV} \text { to } 96 \\
\mathrm{kV} \text { and in LAT } \\
\text { projection from } \\
81 \mathrm{kV} \text { to } 102 \mathrm{kV} \\
\text { and the increase } \\
\text { of SID from } 100 \\
\mathrm{~cm} \text { to } 130 \mathrm{~cm}\end{array}$ & $\begin{array}{l}\text { Dose reduction with } \\
\text { the use of optimised } \\
\text { procedure (higher kV, } \\
\text { FFD, faster film/screen } \\
\text { combination and use of } \\
\text { carbon fibre cassette) } \\
\text { has decreased by } 66 \% \\
\text { with no significant } \\
\text { changes of image } \\
\text { quality }\end{array}$ \\
\hline $\begin{array}{l}\text { Brindhaban } \\
\text { et al., } \\
2005 \text { (23) }\end{array}$ & Kuwait & $\begin{array}{l}\text { Experimental } \\
\text { research } \\
\text { - Phantom } \\
\text { study }\end{array}$ & $\begin{array}{l}\text { Lumbar } \\
\text { spine in AP } \\
\text { projection }\end{array}$ & $\begin{array}{l}\text { The effect of } \\
\text { increased tube } \\
\text { voltage on } \\
\text { radiation dose } \\
\text { and image } \\
\text { quality in two } \\
\text { CR systems. }\end{array}$ & $\begin{array}{l}\text { A chamber } \\
\text { dosimeter was used } \\
\text { for ESD, ovary dose } \\
\text { and effective dose } \\
\text { were calculated } \\
\text { using conversion } \\
\text { factors. } \\
\text { Image quality was } \\
\text { assessed using } \\
\text { visual grading } \\
\text { scale (VGS) based } \\
\text { on quality criteria } \\
\text { by the European } \\
\text { Commission } \\
\text { and the SNR was } \\
\text { calculated. }\end{array}$ & $\begin{array}{l}\text { Three different } \\
\text { tube voltages } \\
\text { were used. } \\
9 \text { evaluators = } \\
5 \text { radiologists, } 1 \\
\text { physicist and } 3 \\
\text { radiographers }\end{array}$ & $\begin{array}{l}\text { The decrease of } \\
\text { ESD, ovary dose } \\
\text { and effective dose } \\
\text { between } 25 \% \text { and } 50 \% \\
\text { depending on the used } \\
\text { CR system. } \\
\text { Significant decrease } \\
\text { of image quality, } \\
\text { however the images } \\
\text { were still diagnostically } \\
\text { acceptable. }\end{array}$ \\
\hline $\begin{array}{l}\text { Geijer and } \\
\text { Persliden, } \\
2005 \text { (24) }\end{array}$ & Sweden & $\begin{array}{l}\text { Experimental } \\
\text { research } \\
\text { - Phantom } \\
\text { study }\end{array}$ & $\begin{array}{l}\text { Lumbar } \\
\text { spine in AP } \\
\text { projection }\end{array}$ & $\begin{array}{l}\text { To evaluate } \\
\text { the relation } \\
\text { between } \mathrm{kV} \\
\text { and image } \\
\text { quality at } \\
\text { the constant } \\
\text { effective dose. }\end{array}$ & $\begin{array}{l}\text { Entrance dose was } \\
\text { recorded with a } \\
\text { solid-state detector, } \\
\text { while organ doses } \\
\text { and effective dose } \\
\text { were calculated } \\
\text { with PCXMC } \\
\text { program (Monte } \\
\text { Carlo simulation). } \\
\text { Image quality was } \\
\text { assessed using } \\
\text { VGS bases on } \\
\text { quality criteria } \\
\text { by the European } \\
\text { Commission by } \\
\text { eight radiologists. }\end{array}$ & $\begin{array}{l}\text { The tube } \\
\text { voltage (kV) } \\
\text { was changed } \\
\text { between } 48 \text { and } \\
125 \text { and the } \\
\text { tube load (mAs) } \\
\text { was adjusted to } \\
\text { keep a constant } \\
\text { effective dose. }\end{array}$ & $\begin{array}{l}\text { At the constant } \\
\text { effective dose, a lower } \\
\text { tube voltage delivers } \\
\text { better image quality } \\
\text { than higher tube } \\
\text { voltage. But due to the } \\
\text { use of AEC which is set } \\
\text { for a constant detector } \\
\text { dose this cannot be } \\
\text { done. }\end{array}$ \\
\hline
\end{tabular}




\begin{tabular}{|c|c|c|c|c|c|c|c|}
\hline RESEARCH & COUNTRY & $\begin{array}{c}\text { RESEARCH } \\
\text { METHOD \& } \\
\text { SUBJECT }\end{array}$ & $\begin{array}{l}\text { INSPECTED } \\
\text { AREA }\end{array}$ & $\begin{array}{l}\text { AIM OF THE } \\
\text { STUDY }\end{array}$ & $\begin{array}{l}\text { MEASURING } \\
\text { EQUIPMENT }\end{array}$ & KEYNOTES & $\begin{array}{l}\text { RESULTS AND } \\
\text { COCNLUSION }\end{array}$ \\
\hline $\begin{array}{l}\text { Clancy } \\
\text { et al., } \\
2010(25)\end{array}$ & Ireland & $\begin{array}{l}\text { Experimental } \\
\text { research } \\
\text { - Phantom } \\
\text { study }\end{array}$ & $\begin{array}{l}\text { Lumbar } \\
\text { spine in AP } \\
\text { and LAT } \\
\text { projection }\end{array}$ & $\begin{array}{l}\text { To determine } \\
\text { the effect } \\
\text { of the use } \\
\text { and different } \\
\text { positioning of } \\
\text { lead shielding } \\
\text { on dose to } \\
\text { ovaries, uterus } \\
\text { and testicles in } \\
\text { lumbar spine } \\
\text { radiography. }\end{array}$ & $\begin{array}{l}\text { Dose to the } \\
\text { mentioned organs } \\
\text { was measured using } \\
\text { TLDs. }\end{array}$ & $\begin{array}{l}\text { They used } \\
\text { different } \\
\text { positioning of } \\
\text { lead shielding } \\
\text { (no shield, tube } \\
\text { side, wrap- } \\
\text { around and } \\
\text { Bucky side). }\end{array}$ & $\begin{array}{l}\text { In the AP projection } \\
\text { dose to the testicles } \\
\text { was decreased by } 42 \% \\
\text { when a tube side apron } \\
\text { was used and for } 36 \% \\
\text { when the wrap-around } \\
\text { apron was used. In } \\
\text { the LAT projection, } \\
\text { the observed dose } \\
\text { reduction to the } \\
\text { testicles was } 12 \% \text { with } \\
\text { the use of wrap-around } \\
\text { apron. No reduction to } \\
\text { other inspected organs } \\
\text { was observed. }\end{array}$ \\
\hline $\begin{array}{l}\text { Olsson } \\
\text { et al., } \\
2010(26)\end{array}$ & Sweden & $\begin{array}{l}\text { Experimental } \\
\text { research - } \\
\text { Phantom and } \\
\text { patient study } \\
(n=3)\end{array}$ & $\begin{array}{l}\text { Lumbar } \\
\text { spine in AP } \\
\text { projection }\end{array}$ & $\begin{array}{l}\text { To determine } \\
\text { the effect of } \\
\text { compression } \\
\text { technique to } \\
\text { obtain the } \\
\text { optimal image } \\
\text { quality and } \\
\text { radiation dose. }\end{array}$ & $\begin{array}{l}\text { Kerma-area product } \\
\text { (KAP) was measured } \\
\text { with a ionisation } \\
\text { chamber. }\end{array}$ & $\begin{array}{l}\text { Compression for } \\
\text { three volunteers } \\
\text { to determine } \\
\text { the effect of } \\
\text { compression was } \\
\text { simulated with } \\
\text { Comp-X (carbon } \\
\text { fibre plate) }\end{array}$ & $\begin{array}{l}\text { With the use of } \\
\text { compression dose } \\
\text { reduction of up to } \\
50 \% \text { or more can be } \\
\text { obtained. }\end{array}$ \\
\hline $\begin{array}{l}\text { Davis in } \\
\text { Hopkins, } \\
2013(27)\end{array}$ & UK & $\begin{array}{l}\text { Experimental } \\
\text { research - } \\
\text { Patient study } \\
(\mathrm{n}=30)\end{array}$ & $\begin{array}{l}\text { Lumbar } \\
\text { spine in LAT } \\
\text { projection }\end{array}$ & $\begin{array}{l}\text { Comparison of } \\
\text { radiation dose } \\
\text { received by } \\
\text { the patient in } \\
\text { LAT projection } \\
\text { of lumbar } \\
\text { spine when } \\
\text { the patient Is } \\
\text { lying on the } \\
\text { side and on the } \\
\text { back with the } \\
\text { horizontal x-ray } \\
\text { beam and its } \\
\text { influence on } \\
\text { image quality. }\end{array}$ & $\begin{array}{l}\text { They measured DAP } \\
\text { using a DAP meter. }\end{array}$ & $\begin{array}{l}\text { Rotating the } \\
\text { patients from } \\
\text { their side to their } \\
\text { back caused an } \\
\text { increase in tissue } \\
\text { thickness. The } \\
\text { simulations of } \\
\text { different lateral } \\
\text { thickness were } \\
\text { carried out using } \\
\text { PMMA. }\end{array}$ & $\begin{array}{l}59 \% \text { of DAP decrease } \\
\text { was found when the } \\
\text { patient was lying on } \\
\text { the side rather than on } \\
\text { the back. With the use } \\
\text { of horizontal central } \\
\text { ray position, the tube } \\
\text { voltage should be } \\
\text { increased to decrease } \\
\text { the radiation dose. }\end{array}$ \\
\hline $\begin{array}{l}\text { Mekiš et al., } \\
2013(28)\end{array}$ & Slovenia & \begin{tabular}{|l|} 
Experimental \\
research - \\
Phantom and \\
patient study \\
( $\mathrm{n}=100$ female \\
patients)
\end{tabular} & $\begin{array}{l}\text { Lumbar } \\
\text { spine in AP } \\
\text { and LAT } \\
\text { projection }\end{array}$ & $\begin{array}{l}\text { To evaluate the } \\
\text { influence of } \\
\text { lead shielding } \\
\text { on dose to } \\
\text { breasts in } \\
\text { lumbar spine } \\
\text { radiography. }\end{array}$ & $\begin{array}{l}\text { Dose was measured } \\
\text { using TLDs for both } \\
\text { projections. }\end{array}$ & $\begin{array}{l}\text { The use of } \\
\text { tube voltage } \\
\text { used in clinical } \\
\text { environment } \\
\text { was not in } \\
\text { accordance } \\
\text { with European } \\
\text { guidelines. }\end{array}$ & $\begin{array}{l}\text { The use of lead } \\
\text { shielding has } \\
\text { decreased the radiation } \\
\text { dose to breasts by } \\
\text { approximately } 80 \% \text {. }\end{array}$ \\
\hline $\begin{array}{l}\text { Chaparian } \\
\text { et al., } \\
2014 \text { (29) }\end{array}$ & Iran & $\begin{array}{l}\text { Experimental } \\
\text { research } \\
\text { - Phantom } \\
\text { study }\end{array}$ & $\begin{array}{l}\text { Lumbar } \\
\text { spine in } \\
\text { different } \\
\text { projections }\end{array}$ & $\begin{array}{l}\text { The aim of the } \\
\text { study was to } \\
\text { determine the } \\
\text { ED, dose to } \\
\text { radiosensitive } \\
\text { organs and } \\
\text { effective risk. }\end{array}$ & $\begin{array}{l}\text { The measurements } \\
\text { of entrance } \\
\text { skin exposure } \\
\text { were performed } \\
\text { using solid-state } \\
\text { dosimeter, while } \\
\text { effective dose and } \\
\text { risk of exposure } \\
\text { induced cancer } \\
\text { death were } \\
\text { calculated using } \\
\text { PCXMC program } \\
\text { (Monte Carlo } \\
\text { simulation). }\end{array}$ & $\begin{array}{l}\text { The use of } \\
\text { different } \\
\text { projections has } \\
\text { a different effect } \\
\text { on radiosensitive } \\
\text { organs as they lie } \\
\text { closer or further } \\
\text { from the primary } \\
\text { field. }\end{array}$ & $\begin{array}{l}\text { Lower effective dose } \\
\text { in PA projection by } \\
51 \% \text { and effective } \\
\text { dose and risk by } 58 \% \\
\text { in comparison to AP } \\
\text { projection. } \\
\text { Lower effective dose } \\
\text { in LLAT projection } \\
\text { by } 53 \% \text { and effective } \\
\text { dose and risk by } 58 \% \\
\text { in comparison to RLAT } \\
\text { projection. }\end{array}$ \\
\hline
\end{tabular}




\begin{tabular}{|c|c|c|c|c|c|c|c|}
\hline RESEARCH & COUNTRY & $\begin{array}{c}\text { RESEARCH } \\
\text { METHOD \& } \\
\text { SUBJECT }\end{array}$ & $\begin{array}{c}\text { INSPECTED } \\
\text { AREA }\end{array}$ & $\begin{array}{l}\text { AIM OF THE } \\
\text { STUDY }\end{array}$ & $\begin{array}{l}\text { MEASURING } \\
\text { EQUIPMENT }\end{array}$ & KEYNOTES & $\begin{array}{l}\text { RESULTS AND } \\
\text { COCNLUSION }\end{array}$ \\
\hline $\begin{array}{l}\text { Davey in } \\
\text { England, } \\
2015 \text { (30) }\end{array}$ & $\begin{array}{l}\text { United } \\
\text { Kingdom }\end{array}$ & $\begin{array}{l}\text { Experimental } \\
\text { research } \\
\text { - Phantom } \\
\text { study }\end{array}$ & $\begin{array}{l}\text { Lumbar } \\
\text { spine } \\
\text { imaging in } \\
\text { AP and PA } \\
\text { projection }\end{array}$ & $\begin{array}{l}\text { Comparing } \\
\text { AP and PA } \\
\text { projection } \\
\text { at various } \\
\text { tube voltage } \\
(\mathrm{kV}) \text { using CR } \\
\text { and compare } \\
\text { effective dose, } \\
\text { dose to organs } \\
\text { and image } \\
\text { quality }\end{array}$ & $\begin{array}{l}\text { ESD was measured } \\
\text { using an ion } \\
\text { chambers in Mult- } \\
\text { O-Meter. Effective } \\
\text { dose and dose to } \\
\text { selected organs was } \\
\text { calculated using } \\
\text { PCXMC program } \\
\text { (Monte Carlo } \\
\text { simulation). The } \\
\text { image quality was } \\
\text { assessed using VGA } \\
\text { by } 5 \text { radiography } \\
\text { students. }\end{array}$ & $\begin{array}{l}\text { The use of PA } \\
\text { projection has an } \\
\text { effect of object } \\
\text { magnification } \\
\text { in comparison } \\
\text { to the AP } \\
\text { projection. }\end{array}$ & $\begin{array}{l}\text { Magnification in the PA } \\
\text { projection was } 8 \% \text {. } \\
\text { The effective dose } \\
\text { reduction was } 19.7 \% \\
\text { and the organ that } \\
\text { had the most dose } \\
\text { reduction ( } 74 \%) \text { was the } \\
\text { stomach. } \\
\text { There were no } \\
\text { significant differences } \\
\text { between the images } \\
\text { made in AP and PA } \\
\text { projection. }\end{array}$ \\
\hline $\begin{array}{l}\text { Ben-Shlomo } \\
\text { et al., } \\
2016 \text { (31) }\end{array}$ & Israel & $\begin{array}{l}\text { Experimental } \\
\text { research } \\
\text { - Phantom } \\
\text { study }\end{array}$ & $\begin{array}{l}\text { Lumbar } \\
\text { spine in four } \\
\text { different } \\
\text { projections } \\
\text { AP, PA, LLAT, } \\
\text { RLAT }\end{array}$ & $\begin{array}{l}\text { To calculate } \\
\text { and compare } \\
\text { the effective } \\
\text { dose for } \\
\text { lumbar spine } \\
\text { radiography } \\
\text { for adults and } \\
10 \text {-year-old } \\
\text { children. }\end{array}$ & $\begin{array}{l}\text { The calculations } \\
\text { were made using } \\
\text { PCXMC program } \\
\text { (Monte Carlo } \\
\text { simulation). }\end{array}$ & $\begin{array}{l}\text { The authors want } \\
\text { to determine } \\
\text { the less } \\
\text { radiosensitive } \\
\text { side of the body } \\
\text { for lumbar spine } \\
\text { imaging. }\end{array}$ & $\begin{array}{l}\text { RLAT projection has } \\
\text { been proven to deliver } \\
28 \% \text { lower ED in } \\
\text { comparison to LLAT } \\
\text { projection. } \\
\text { PA projection has been } \\
\text { proven to deliver } 48 \% \\
\text { lower ED in comparison } \\
\text { to the AP projection. }\end{array}$ \\
\hline $\begin{array}{l}\text { Karami, in } \\
\text { Zabihzadeh } \\
2017 \text { (32) }\end{array}$ & Iran & $\begin{array}{l}\text { Retrospective } \\
\text { study - } 830 \\
\text { images of } \\
\text { lumbar spine } \\
\text { in the AP } \\
\text { projection }\end{array}$ & $\begin{array}{l}\text { Lumbar } \\
\text { spine in AP } \\
\text { projection }\end{array}$ & $\begin{array}{l}\text { To evaluate } \\
\text { the collimation } \\
\text { protocol in two } \\
\text { Iranian general } \\
\text { hospitals. }\end{array}$ & $\begin{array}{l}\text { A mathematical } \\
\text { formula to } \\
\text { determine the } \\
\text { oversized primary } \\
\text { field was used. }\end{array}$ & $\begin{array}{l}\text { The authors state } \\
\text { that this has } \\
\text { happened due to } \\
\text { implementation } \\
\text { of digital } \\
\text { detectors. }\end{array}$ & $\begin{array}{l}\text { The area of diagnostic } \\
\text { interest was } 1.26 \text { times } \\
\text { higher than it is supposed } \\
\text { to be - this cause higher } \\
\text { dose too. In } 62 \% \text { of } \\
\text { radiographs evaluated, } \\
\text { ovaries were included in } \\
\text { the primary beam. }\end{array}$ \\
\hline $\begin{array}{l}\text { Robinson } \\
\text { et al., } \\
2017 \text { (33) }\end{array}$ & Sweden & $\begin{array}{l}\text { Experimental } \\
\text { research } \\
\text { - Phantom } \\
\text { study }\end{array}$ & $\begin{array}{l}\text { Thoraco- } \\
\text { lumbar } \\
\text { spine } \\
\text { (scoliosis } \\
\text { protocol) }\end{array}$ & $\begin{array}{l}\text { The aim was } \\
\text { to determine } \\
\text { the differences } \\
\text { to organ dose, } \\
\text { effective dose } \\
\text { and effective } \\
\text { risk comparing } \\
\text { tight and loose } \\
\text { collimation in } \\
\text { thoraco-lumbar } \\
\text { spine imaging. }\end{array}$ & $\begin{array}{l}\text { The TLDs were used } \\
\text { to measure ESD, } \\
\text { organ doses and the } \\
\text { effective risk were } \\
\text { calculated using } \\
\text { a mathematical } \\
\text { formula. }\end{array}$ & $\begin{array}{l}\text { The patients } \\
\text { that suffer from } \\
\text { scoliosis usually } \\
\text { get imaged quite } \\
\text { frequently and } \\
\text { because they are } \\
\text { at a young age a } \\
\text { tight collimation } \\
\text { protocol should } \\
\text { be used to } \\
\text { protect as many } \\
\text { organs. }\end{array}$ & $\begin{array}{l}\text { The organ dose with the } \\
\text { use of loose collimation } \\
\text { protocol increased from } \\
31 \text { to } 571 \% \\
\text { The effective risk } \\
\text { vas } 3.3 \text { times higher } \\
\text { when using a loose } \\
\text { collimation. }\end{array}$ \\
\hline $\begin{array}{l}\text { Shanahan, } \\
2017 \text { (34) }\end{array}$ & Australia & $\begin{array}{l}\text { Phantom } \\
\text { study }\end{array}$ & $\begin{array}{l}\text { Lumbar } \\
\text { spine in AP } \\
\text { projection }\end{array}$ & $\begin{array}{l}\text { To compare } \\
\text { the ESD based } \\
\text { on the } 15 \% \\
\mathrm{kVp} \text { rule and } \\
\text { simplified } 10 \\
\mathrm{kVp} \text { rule for CR } \\
\text { and DR systems } \\
\text { (system } 1 \\
\text { and } 2 \text { ), and } \\
\text { for Projection } \\
\text { VR - virtual } \\
\text { radiography } \\
\text { simulation } \\
\text { (system } 3 \text { ). }\end{array}$ & $\begin{array}{l}\text { The ESD was } \\
\text { measured using } \\
\text { NanoDOT, single } \\
\text { point dosimeters. }\end{array}$ & $\begin{array}{l}\text { The 15\% rule } \\
\text { states that if you } \\
\text { increase the tube } \\
\text { voltage for } 15 \% \text {, } \\
\text { then the tube } \\
\text { time current } \\
\text { product has to } \\
\text { be decreased by } \\
50 \% \text { to get the } \\
\text { same exposure. } \\
\text { The exposure } \\
\text { maintenance } \\
\text { formula uses the } \\
\text { increase in SID. }\end{array}$ & $\begin{array}{l}\text { Increasing kVp resulted } \\
\text { in reduction of ESD } \\
\text { by 59,5\% (system } 1 \text { ), } \\
60,8 \% \text { (system } 2 \text { ) and } \\
60,3 \% \text { (system 3). } \\
\text { Increasing SID resulted } \\
\text { in reduction of ESD by } \\
22,3 \% \text { (system } 1 \text { ), 18,8\% } \\
\text { (system2) and } 23,5 \% \\
\text { (system 3). }\end{array}$ \\
\hline $\begin{array}{l}\text { Alukić et al., } \\
2018 \text { (35) }\end{array}$ & Slovenia & $\begin{array}{l}\text { Experimental } \\
\text { research - } \\
\text { Phantom and } \\
\text { patient study } \\
(\mathrm{n}=100)\end{array}$ & $\begin{array}{l}\text { Lumbar } \\
\text { spine, AP } \\
\text { and PA } \\
\text { projection }\end{array}$ & $\begin{array}{l}\text { Compare } \\
\text { patient } \\
\text { radiation dose } \\
\text { and image } \\
\text { quality using } \\
\text { AP and PA } \\
\text { projection. }\end{array}$ & $\begin{array}{l}\text { DAP meter was } \\
\text { used to measure } \\
\text { DAP and effective } \\
\text { dose was calculated } \\
\text { using PCXMC } \\
\text { program (Monte } \\
\text { Carlo simulation). } \\
\text { image quality was } \\
\text { evaluate by three } \\
\text { radiologists using } \\
\text { criteria in European } \\
\text { guidelines. }\end{array}$ & $\begin{array}{l}\text { Body mass } \\
\text { index (BMI), DAP, } \\
\text { exposure index } \\
\text { (EXI), mAs, image } \\
\text { field size and } \\
\text { source to patient } \\
\text { distance were } \\
\text { acquired. }\end{array}$ & $\begin{array}{l}\text { No significant difference } \\
\text { in image field size, DAP } \\
\text { and image quality but } \\
\text { in a PA projection a } \\
\text { significant reduction of } \\
\text { thickness of abdomen } \\
\text { by } 10 \% \text {, DAP by } 27 \% \\
\text { and effective dose } \\
\text { by } 53 \% \text { compared } \\
\text { to AP projection. No } \\
\text { significant difference in } \\
\text { image quality between } \\
\text { AP and PA projection. }\end{array}$ \\
\hline
\end{tabular}




\begin{tabular}{|c|c|c|c|c|c|c|c|}
\hline RESEARCH & COUNTRY & $\begin{array}{c}\text { RESEARCH } \\
\text { METHOD \& } \\
\text { SUBJECT }\end{array}$ & $\begin{array}{c}\text { INSPECTED } \\
\text { AREA }\end{array}$ & $\begin{array}{c}\text { AIM OF THE } \\
\text { STUDY }\end{array}$ & $\begin{array}{l}\text { MEASURING } \\
\text { EQUIPMENT }\end{array}$ & KEYNOTES & $\begin{array}{l}\text { RESULTS AND } \\
\text { COCNLUSION }\end{array}$ \\
\hline $\begin{array}{l}\text { Green et al., } \\
2019 \text { (36) }\end{array}$ & $\begin{array}{l}\text { United } \\
\text { Kingdom }\end{array}$ & $\begin{array}{l}\text { Experimental } \\
\text { research - } \\
\text { Patient study } \\
(\mathrm{n}=80 ; 60-100 \\
\mathrm{kg})\end{array}$ & $\begin{array}{l}\text { Lumbar } \\
\text { spine, AP } \\
\text { and PA } \\
\text { projection }\end{array}$ & $\begin{array}{l}\text { Evaluate dose } \\
\text { and image } \\
\text { quality in both } \\
\text { projections and } \\
\text { survey current } \\
\text { UK practice }\end{array}$ & $\begin{array}{l}\text { DAP meter was } \\
\text { used to measure the } \\
\text { DAP and effective } \\
\text { dose was calculated } \\
\text { using PCXMC } \\
\text { program (Monte } \\
\text { Carlo simulation). } \\
\text { Image quality was } \\
\text { evaluate by two } \\
\text { radiologist using } \\
\text { criteria in European } \\
\text { guidelines. }\end{array}$ & $\begin{array}{l}\text { BMI, DAP and } \\
\text { mAs were } \\
\text { acquired }\end{array}$ & $\begin{array}{l}\text { Effective dose was } \\
\text { reduced by } 41 \% \text { when } \\
\text { PA projection was used } \\
\text { with no difference in } \\
\text { image quality. }\end{array}$ \\
\hline $\begin{array}{l}\text { Alukić et al., } \\
2019 \text { (37) }\end{array}$ & Slovenia & $\begin{array}{l}\text { Experimental } \\
\text { research - } \\
\text { Patient study } \\
(n=100)\end{array}$ & $\begin{array}{l}\text { Lumbar } \\
\text { spine, AP } \\
\text { and PA } \\
\text { projection }\end{array}$ & $\begin{array}{l}\text { Determine the } \\
\text { effect of the } \\
\text { PA projection } \\
\text { on effective } \\
\text { dose and the } \\
\text { absorbed organ } \\
\text { dose }\end{array}$ & $\begin{array}{l}\text { Calculation with } \\
\text { PCXMC program } \\
\text { (Monte Carlo } \\
\text { simulation). }\end{array}$ & $\begin{array}{l}\text { Image quality } \\
\text { was not } \\
\text { measured. }\end{array}$ & $\begin{array}{l}\text { Significant reduction } \\
\text { of ESD by } 33 \% \text { and, } \\
\text { effective dose by } 53 \% \\
\text { and } 64 \% \text { average } \\
\text { reduction of the } \\
\text { absorbed organ doses } \\
\text { when the PA projection } \\
\text { was used. }\end{array}$ \\
\hline $\begin{array}{l}\text { Pazanin } \\
\text { et al., } \\
2020 \text { (38) }\end{array}$ & Croatia & $\begin{array}{l}\text { Experimental } \\
\text { research - } \\
\text { Patient study } \\
(\mathrm{n}=110)\end{array}$ & $\begin{array}{l}\text { Lumbar } \\
\text { spine, AP } \\
\text { and LAT } \\
\text { projection }\end{array}$ & $\begin{array}{l}\text { Determine } \\
\text { the influence } \\
\text { of optimal } \\
\text { and standard } \\
\text { (non-optimal) } \\
\text { collimation on } \\
\text { radiation dose } \\
\text { and image } \\
\text { quality }\end{array}$ & $\begin{array}{l}\text { DAP meter was } \\
\text { used to measure } \\
\text { the DAP, absorbed } \\
\text { and effective dose } \\
\text { were calculated } \\
\text { using PCXMC } \\
\text { program (Monte } \\
\text { Carlo simulation). } \\
\text { Image quality was } \\
\text { evaluate by two } \\
\text { radiologist and a } \\
\text { radiographer using } \\
\text { criteria in European } \\
\text { guidelines. }\end{array}$ & $\begin{array}{l}\text { BMI, exposure } \\
\text { conditions, } \\
\text { image field size } \\
\text { and DAP were } \\
\text { acquired. }\end{array}$ & $\begin{array}{l}\text { Optimal collimation } \\
\text { reduced image field size } \\
\text { by } 40 \% \text {, effective dose } \\
\text { by } 48 \% \text { and absorbed } \\
\text { dose by } 41 \% \text { for the } \\
\text { AP and effective dose } \\
\text { by } 48 \% \text { and absorbed } \\
\text { dose by } 10 \% \text { for the } \\
\text { LAT projection. Image } \\
\text { quality improves } \\
\text { by } 24 \% \text { in the LAT } \\
\text { projection, and } \\
\text { showed no statistically } \\
\text { significant difference } \\
\text { for AP projection with } \\
\text { the use of optimal } \\
\text { collimation. }\end{array}$ \\
\hline $\begin{array}{l}\text { Peacock } \\
\text { et al., } \\
2020 \text { (39) }\end{array}$ & Australia & $\begin{array}{l}\text { Retrospective } \\
\text { study - } 91 \\
\text { images of } \\
\text { lumbar spine } \\
\text { in the LAT } \\
\text { projection }\end{array}$ & $\begin{array}{l}\text { Lumbar } \\
\text { spine in LAT } \\
\text { projection }\end{array}$ & $\begin{array}{l}\text { To assess the } \\
\text { effects of the } \\
\text { high tube } \\
\text { potential on } \\
\text { image quality } \\
\text { using DR } \\
\text { system and } \\
\text { validate effect } \\
\text { on dose saving } \\
\text { technique } \\
\end{array}$ & \begin{tabular}{|l|} 
Collection of data \\
from PACS system. \\
Image quality \\
was assessed \\
by five senior \\
radiographers using \\
a 15-point visual \\
grading analysis.
\end{tabular} & $\begin{array}{l}\mathrm{kV}, \mathrm{mAs} \text {, } \\
\text { deviation index } \\
\text { and DAP were } \\
\text { acquired. }\end{array}$ & $\begin{array}{l}\text { The reduction of DAP } \\
\text { with the use of higher } \\
\mathrm{kVp} \text { was shown for } 40 \\
\text { lateral lumbar spine } \\
\text { radiographs with no } \\
\text { statistically significant } \\
\text { difference in image } \\
\text { quality. }\end{array}$ \\
\hline $\begin{array}{l}\text { Bellizzi } \\
\text { et al., } \\
2020(40)\end{array}$ & Malta & $\begin{array}{l}\text { Experimental } \\
\text { research - } \\
\text { Phantom and } \\
\text { patient study } \\
(\mathrm{n}=50)\end{array}$ & $\begin{array}{l}\text { Lumbar } \\
\text { spine in LAT } \\
\text { projection }\end{array}$ & $\begin{array}{l}\text { To investigate } \\
\text { the possibility } \\
\text { of replacing an } \\
\text { antiscatter grid } \\
\text { with an air gap } \\
\text { technique to } \\
\text { reduce dose. }\end{array}$ & \begin{tabular}{|l|} 
DAP meter was \\
used to measure the \\
DAP. Image quality \\
was assessed by five \\
radiologists using \\
a 15 -point visual \\
grading analysis.
\end{tabular} & / & $\begin{array}{l}\text { Application of air gap } \\
\text { technique resulted in a } \\
\text { statistically significant } \\
\text { reduction in DAP by } \\
72 \% \text {, image quality } \\
\text { between the two } \\
\text { techniques was not } \\
\text { significant. }\end{array}$ \\
\hline $\begin{array}{l}\text { Lai et al., } \\
2020 \text { (41) }\end{array}$ & Australia & $\begin{array}{l}\text { Experimental } \\
\text { research - } \\
\text { Phantom } \\
\text { study }\end{array}$ & $\begin{array}{l}\text { Lumbar } \\
\text { spine in LAT } \\
\text { projection }\end{array}$ & $\begin{array}{l}\text { Determine } \\
\text { the influence } \\
\text { of different } \\
\text { exposure } \\
\text { parameters } \\
\text { - source to } \\
\text { detector } \\
\text { distance, tube } \\
\text { potential, tube } \\
\text { time current } \\
\text { and additional } \\
\text { copper filter for } \\
\text { reduction of } \\
\text { effective dose. }\end{array}$ & $\begin{array}{l}\text { Effective dose } \\
\text { was calculated } \\
\text { using PCXMC } \\
\text { program (Monte } \\
\text { Carlo simulation). } \\
\text { Contrast-to- } \\
\text { noise ratio and } \\
\text { magnification were } \\
\text { calculated using } \\
\text { ImageJ. }\end{array}$ & $\begin{array}{l}\text { Exposure factors, } \\
\text { SSD, focal- } \\
\text { skin distance, } \\
\text { collimation field } \\
\text { and additional } \\
\text { filtration } \\
\text { parameters } \\
\text { were acquired } \\
\text { for each image } \\
\text { acquisition. }\end{array}$ & $\begin{array}{l}\text { The highest effective } \\
\text { dose was found with } \\
\text { the use of lowest SSD, } \\
\text { lowest tube potential, } \\
\text { highest tube time } \\
\text { current and without } \\
\text { additional copper filter. }\end{array}$ \\
\hline
\end{tabular}


the lumbar spine can be optimised based on their proposed methodology. The results cannot be generalised due to the uniqueness of each study methodology and measurement technique.

With the lowering of tube voltage $(\mathrm{kV})$, the patient's dose can be reduced $(21-24,34,39,41)$. It has already been proven that the increase of tube voltage increases the penetration of x-rays, and as a consequence, the automatic exposure control terminates exposure earlier due to more $\mathrm{x}$-rays hitting the ionising chamber of AEC. The negative effect of tube voltage increase is its influence on image quality. The use of modern materials and digital technology that offers image postprocessing, such as changing the window centre and level, can reduce the negative effect of tube voltage increase on image quality (24). In the past, the increase of tube voltage in screen-film technology has led to a decrease of image contrast (4). The inspected papers investigated the influence of tube voltage increase performed on different imaging systems (screen-film and digital). Therefore, the results between studies differ. A film-screen system was in use in research until 2004. The research on two CR detectors was firstly mentioned in 2005 (23).

Therefore, in the literature review, it could be observed how measurement equipment for dose has changed over the years and where they first used TLDs and chamber dosimeters (1623,25,26). In 2013, Davis and Hopkins first mentioned the use of the DAP meter (27).

In the early years, dose on organs could not be measured. The record of organ dose was first mentioned in 2005 (24), and then again nine years later in 2014 (29). Since 2014, the Monte Carlo simulation has been used in eight different articles (29$31,35-38,41)$. For calculations of an effective dose, organ dose weight and height of the patient, imaging field size, DAP, and total filtration are needed (42).

In studies that investigate an alternative projection in lumbar spine radiography $(19,27,29-31,35-37)$, researchers should be careful that the radiograph's quality remains optimal and that the changing of the position does not result in excessive magnification of the inspected object. As described in the reviewed papers, the magnification of the inspected object can be enlarged up to the point that it still does not interfere with the diagnostically important information and radiologist's perception. The further away the inspected object is from the image receptor, the greater the magnification is (19). The use of alternative projections is limited in its use since it cannot be used in all diagnostic departments due to the patient's status or mobility. Changing the projection from AP to PA projection in lumbar spine radiography greatly influences dose reduction to different organs in the patient's body. Due to anatomy, some bones in the human body (pelvis) can work as a shield for some organs that lie behind the bone structure. Another advantage of the PA projection is that some radiosensitive organs lie further from the irradiation source and, due to the inverse square law, those organs receive a lower radiation dose than in the AP projection.

Lead shielding has proven to be an effective dose reduction technique when used inside or outside the primary field. The use of lead protection over the radiosensitive organs can decrease the dose received by those organs $(25,28)$. Proper collimation of the primary beam also has a considerable effect on the patient's radiation dose $(32,33,38)$. When deciding which organs to shield or put outside the primary field, the ICRP document must be considered to determine which organs have the highest tissue weighting factors (3). However, tissue weighting factors change over time based on the results of studies investigating the ionising radiation effect on the human body, the organs, and cells. For example, before the year 2007, the gonads were the organ with the highest tissue weighting factor (6), so the research was mainly focused on dose reduction to the gonads. After the new publication from the ICRP in 2007, the gonads are now the sixth organ based on tissue weighting factor (3). The organs with the highest tissue weighting factor of 0.12 are now the breast, lungs, bone marrow, stomach, and colon, so the research of dose reduction has nowadays changed to described (most radiosensitive) organs.

Along with the most frequently described research methods, other reviewed methods have also been proven to be effective as a dose reduction technique, such as the change of the patient position based on the tube side (cathode-anode) (20). It has been proven that the radiation intensity is lower on the anode side; therefore, the part of the body with a smaller diameter (legs) has to be on that side of the x-ray tube and the larger diameter (head) on the cathode side (14). Also, a well-known example of the compression of the body part is in daily use in mammography since the dose reduction to the patient and improved image quality were proven. That kind of dose reduction technique can also be implemented to other positioning in radiography (26). The ALARA principle states that even with a minimum dose, if receiving that dose has no benefit, it should be avoided. This was indicated in a study that examined the necessity for a third projection (lumbosacral joint in lateral view). It was found that the use of the third projection doubled the dose compared to two projections (AP and lateral) (16). Finally, a significant manner of optimising the dose is by using the air gap technique instead of the antiscatter grid (40). The reduction in scattered radiation reaching the detector is achieved by increasing the distance between the effective scatter point source and the image receptor. This increased distance increases the chance that the scatter radiations path will not reach the receptor and; therefore, not reduce image contrast.

We recommend that the studies that were performed only on an anthropomorphic phantom be conducted also on patients in order to determine their influence on dose reduction on actual patients before using them in the clinical environment. In dose optimisation, image quality cannot be decreased to the extent that the diagnostically important information is lost. If diagnostically important information was missed, this would result in even greater harm to the patient in comparison to the damage that would result due to ionising radiation. In a large variety of the reviewed papers, the influence of dose optimisation on image quality has not been inspected $(17,20,34,37,25-29,31-33)$. When the image quality was inspected, all three groups of experts were used, but not all together. We propose that all three groups of experts (radiographer, radiologist, and medical physicist) evaluate the image quality to obtain the optimal results due to their different backgrounds. Radiologists would inspect the diagnostic part of the image, radiographers the technical part of the image and the medical physicists would give an objective quality of the image. 
Due to rapid changes in technology, new ideas and methods of dose reduction techniques will surely appear. The researchers should remember to inspect the effects of the optimisation technique on image quality and not only on radiation dose.

\section{Limitations of the systematic review}

This review has screened a variety of research papers in the field of dose reduction in lumbar spine radiography that may lead to easier implication in a clinical setting. Based on the reviewed literature, this type of qualitative study was not found in this field.

Limitations of our review are that only articles in English were included in the review and that not all papers examined the effects of dose optimisation on image quality.

\section{CONCLUSION}

Regardless of the many uses and advantages of ionising radiation in X-ray diagnostics, it has a negative effect on the human body, so the ALARA principle must be observed. This means that the patient is imaged with the lowest possible radiation dose with optimal image quality based on the expected pathology. Based on the inspected studies, it can be concluded that there are many different ways to achieve dose reduction in lumbar spine radiography, while keeping the quality of the images in the diagnostically acceptable range. The methods studied for dose optimisation are different lead shield positioning, proper collimation, alternative patient positioning, patient positioning based on the orientation of the X-ray tube, increasing the source-to-image receptor distance, and changing the exposure factors, among others. All the methods studied were found to be effective in dose optimisation as the average dose reduction in all the studies was $44 \%$. The studies that investigated the effect of dose optimisation on image quality concluded that there was no significant reduction in image quality and that all images were still diagnostically acceptable. We did not find a large systematic review examining dose optimisation techniques and image quality in lumbar spine radiography. Due to a wide variety of procedures, techniques, and modalities in radiology, this cannot be generalised to all diagnostic procedures. Therefore, a targeted review should be performed separately for each procedure and modality.

\section{REFERENCES}

1. Aldrich JE, Duran E, Dunlop P, Mayo JR. Optimization of dose and image quality for computed radiography and digital radiography. J Digit Imaging. 2006;19(2):126-31.

2. Tabor L, Jevtić $V$, Pavčnik D. Radiologija: diagnostične slikovne metode in intervencijska radiologija. Med Razgl. 2001;(3):135-49.

3. International Commission on Radiological Protection. The 2007 recommendations of the International Commission on Radiological Protection. Valentin J, editor. Orlando: Elsevier, published for the International Commission on Radiological Protection, cop. 2007; 2007. 332 p.
4. European Commission. European Guidlines on Quality Criteria for Diagnostic Radiographic Images, EUR 16260 EN [Internet]. 1996. Available from: https://www.sprmn. pt/pdf/EuropeanGuidelineseur16260.pdf

5. Medic M, Zibert J, Mekis N. Radiološka tehnologija 1, učbenik za študente radiološke tehnologije. Ljubljana: Zdravstvena fakulteta; 2017.

6. International Commission on Radiological Protection. 1990 recommendations of the International commission on radiological protection. Oxford [etc.]: Pergamon; 1991. VII, 201. (ICRP publication; vol. 60).

7. Jarvik JG, Comstock BA, James KT, Avins AL, Bresnahan BW, Deyo RA, et al. HHS Public Access. 2016;45(0 0):157-63.

8. Rupreht M. Slikovne preiskave v diagnostiki hrbtenice. 2012. 97-104 p.

9. Frank ED, Stears JG, Gray JE, Winkler NT, Hoffman AD. Use of the posteroanterior projection: A method of reducing X-ray exposure to specific radiosensitive organs. Radiol Technol. 1983;

10. Hart D, Wall B, Hillier M, Shrimpton P. HPA-CRCE-012 Frequency and collective dose for medical and dental X-ray examinations in the UK, 2008 [Internet]. Health Protection Agency HPA-CRCE-012. 2010. 1-52 p. Available from: http://scholar.google.com/scholar?hl=en\&btnG= Search\&q=intitle:Frequency+and+Collective+Dose+fo $r+$ Medical+and+Dental+X-ray+Examinations+in+the+ UK,$++2008 \# 0$

11. Long BW, Frank ED, Ehrlich RA. Radiography Essentials for Limited Practice [Internet]. Elsevier; 2016. Available from: https://books.google.si/books?id=E7jYjwEACAAJ

12. Nic An Ghearr FA, Brennan PC. The PA projection of the abdomen: A dose reducing technique. Radiography. 1998;4(3):195-203.

13. European Union. Diagnostic Reference Levels in Thirtysix European Countries. Part 2/2 [Internet]. Radiation Protection $N^{\circ} 180.2015$. Available from: https://ec.europa. eu/energy/sites/ener/files/documents/RP180 part2.pdf

14. Medič $M$, Mekiš $N$. Diagnostične radiološke metode: skeletna diagnostika: učbenik za študente radiološke tehnologije. Ljubljana: Zdravstvena Fakulteta; 2018. $1-478 \mathrm{p}$.

15. Martin CJ. Optimisation in general radiography. Biomed Imaging Interv J. 2007;3(2).

16. Moilanen A, Kokko M, Pitkfinen M. Gonadal dose reduction in lumbar spine radiography. Skeletal Radiol. 1983;9(3):153-6.

17. Dilger R, Egan I, Hayek R. Effects of Focus Film Distance (FFD) variation on entrance testicular dose in lumbar- 
pelvic radiography. Vol. 6, Australasian chiropractic \& osteopathy: journal of the Chiropractic \& Osteopathic College of Australasia. 1997. p. 18-23.

18. Brennan PC, Nash M. Increasing FFD: An effective dosereducing tool for lateral lumbar spine investigations. Radiography. 1998;4(4):251-9.

19. Brennan PC, Madigan E. Lumbar spine radiology: analysis of the posteroanterior projection. Eur Radiol. 2000;10(7):1197-201.

20. Fung KKL, GilboyWB."Anode heel effect"on patient dose in lumbar spine radiography. Br J Radiol. 2000;73(869):5316.

21. Doherty $P$, O'Leary D, Brennan PC. Do CEC guidelines under-utilise the full potential of increasing $k V p$ as a dose-reducing tool? Eur Radiol. 2003;13(8):1992-9.

22. Grondin $Y$, Matthews K, McEntee M, Rainford L, Casey M, Tonra $\mathrm{M}$, et al. Dose-reducing strategies in combination offers substantial potential benefits to females requiring X-ray examination. Radiat Prot Dosimetry. 2004;108(2):123-32.

23. Brindhaban A, Al Khalifah K, AIWathiqi G, Al Ostath H. Effect of $x$-ray tube potential on image quality and patient dose for lumbar spine computed radiography examinations. Australas Phys Eng Sci Med. 2005;28(4):216-22.

24. Geijer H, Persliden J. Varied tube potential with constant effective dose at lumbar spine radiography using a flatpanel digital detector. Radiat Prot Dosimetry. 2005;114(13):240-5.

25. Clancy CL, O'Reilly G, Brennan PC, McEntee MF. The effect of patient shield position on gonad dose during lumbar spine radiography. Radiography [Internet]. 2010;16(2):131-5. Available from: http://www.sciencedirect.com/science/ article/pii/S1078817409000984

26. Olsson ML, Tingberg A, Mattsson S. A Phantom study showing the importance of compression in conventional diagnostic X-ray examinations. Radiat Prot Dosimetry. 2010;139(1-3):78-80.

27. Davis AT, Hopkins SA. Optimisation of patient dose for the horizontal beam technique in lateral lumbar spine radiographic examinations. Br J Radiol. 2013;86(1027):2-5.

28. Mekis N, Zontar D, Skrk D. The effect of breast shielding during lumbar spine radiography. Radiol Oncol. 2013;47(1):26-31.

29. Chaparian A, Kanani A, Baghbanian M. Reduction of radiation risks in patients undergoing some $\mathrm{X}$-ray examinations by using optimal projections: A Monte Carlo program-based mathematical calculation. J Med Phys. 2014;39(1):32-9.
30. Davey E, England A. AP versus PA positioning in lumbar spine computed radiography: Image quality and individual organ doses. Radiography [Internet]. 2015;21(2):188-96. Available from: http://dx.doi. org/10.1016/j.radi.2014.11.003

31. Ben-Shlomo A, Bartal G, Mosseri M, Avraham B, Leitner $Y$, Shabat $\mathrm{S}$. Effective dose reduction in spine radiographic imaging by choosing the less radiation-sensitive side of the body. Spine J [Internet]. 2016;16(4):558-63. Available from: http://dx.doi.org/10.1016/j.spinee.2015.12.012

32. Karami V, Zabihzadeh $M$. Beam Collimation during Lumbar Spine Radiography: A Retrospective Study. J Biomed Phys Eng. 2017;7(2):101-6.

33. Robinson JB, Ali RM, Tootell AK, Hogg P. Does collimation affect patient dose in antero-posterior thoraco-lumbar spine? Radiography[Internet].2017;23(3):211-5. Available from: http://dx.doi.org/10.1016/j.radi.2017.03.012

34. Shanahan MC. A pilot study investigating two dose reduction techniques for AP lumbar spine radiography using direct dosimetry and Projection VR. Radiography [Internet]. 2017;23(3):222-8. Available from: http:// dx.doi.org/10.1016/j.radi.2017.03.015

35. Alukic E, Skrk D, Mekis N. Comparison of anteroposterior and posteroanterior projection in lumbar spine radiography. Radiol Oncol. 2018;52(4):468-74.

36. Green C, Karnati G, Thomson K, Subramanian A. Lumbar spine radiographs - Is it time for widespread adoption of posteroanterior projection? Br J Radiol. 2019;92(1103):1-6.

37. Alukić E, Mekiš N. LUMBAR SPINE RADIOGRAPHY: LOWER ORGAN DOSE WITH THE USE OF PA PROJECTION. Radiat Prot Dosimetry. 2019;186(4):507-12.

38. Pazanin A, Skrk D, O'Driscoll JC, Mcentee MF, Mekis N. OPTIMAL COLLIMATION SIGNIFICANTLY IMPROVES LUMBAR. Radiat Prot Dosimetry. 2020;189(4):420-7.

39. Peacock NE, Steward AL, Riley PJ. An evaluation of the effect of tube potential on clinical image quality using direct digital detectors for pelvis and lumbar spine radiographs. J Med Radiat Sci. 2020;260-8.

40. Bellizzi A, Zarb F. Radiography Optimisation of the lateral lumbar spine projection using an air-gap technique. Radiography [Internet]. 2020;26(3):227-33. Available from: https://doi.org/10.1016/j.radi.2019.12.008

41. Lai ZH, Sá dos Reis C, Sun Z. Effective dose and image optimisation of lateral lumbar spine radiography: a phantom study. Eur Radiol Exp. 2020;4(13).

42. Tapiovaara M, Siiskonen T. A PCXMC - A Monte Carlo program for calculating patient doses in medical $x$-ray examinations. 2nd ed. 2008. 